\title{
Cupido e Psiquê: o leitor e a curiositas nas Metamorfoses de Apuleio
}

\author{
Rayana da Costa Teles Barreto*, Isabella Tardin Cardoso.
}

\section{Resumo}

O presente trabalho visa investigar a história Cupido e Psiquê (Met., IV, 28 - VI, 24), episódio central da obra Metamorphoses (Metamorphoses) de Apuleio (125-170? d.C.), ou O Asno de Ouro (Asinus Aureus) como foi comumente denominada ainda na Antiguidade Tardia. Embora essa história tenha sido considerada mera digressão por muitos estudiosos, interpretações mais recentes apontam a complexidade alusiva do texto (Harrison, 2003) e, com isso, defendem, inclusive, a integração da história de Cupido e Psiquê às Metamorfoses em sua totalidade. Para averiguar tal hipótese, no primeiro momento da pesquisa, observamos as passagens relativas à caracterização de Lúcio e de Psiquê, a fim de compreender quais aspectos narratológicos são empregados no texto para conferir a proximidade entre os personagens. No segundo momento, tratamos da questão do leitor, por meio de apreciação de trechos com menção do termo "leitor", "leitura" e correlatos, nos quais o leitor é abertamente referido em meio à narrativa, a fim de analisar as imagens de leitor à luz de estudos de Teorias da Recepção (e.g. Iser 2002 [1989]).

\section{Palavras-chave:}

Cupido e Psiquê, Metamorfoses/O Asno de Ouro, Leitor.

\section{Introdução}

Embora atualmente seja consensual entre os estudiosos que as Metamorfoses remanesceram na integra, sua natureza episódica nos apresenta várias histórias (uariae fabulae), dentre as quais se encontra a bela narrativa de Cupido e Psiquê: o episódio central deste romance e o principal objeto de estudo de nossa pesquisa. A ficção apuleiana reúne efetivamente assuntos variados. O evento central do romance, por exemplo, marcado entre outros aspectos pelos universos da ars magica e da bestialidade, trata da história de Lúcio, que, em consequência de sua curiosidade, transforma-se em um asno. Por outro lado, a história de Cupido de Psiquê é marcada por uma atmosfera mítica. Nela nos deparamos também com a curiosidade de uma jovem, característica tal responsável pelos percalços que a personagem enfrenta em sua peregrinatio. Trata-se de uma ficção em prosa modernamente classificada como romance antigo, que já foi criticada pelo seu caráter episódico, pela temática abordada e por seu formato literário, bem como pela própria imagem atribuída ao autor. Sua recepção produziu ao longo do tempo leituras e interpretações muitas vezes contraditórias, 0 que suscitou considerações tanto negativas quanto positivas sobre seu teor.

\section{Resultados e Discussão}

$\mathrm{Na}$ primeira etapa deste projeto, analisamos aspectos narratológicos da ficção apuleiana, a partir da seleção criteriosa de excertos que caracteriza as personagens Psiquê e Lúcio a partir do viés da curiositas, bem como traduzimos tais passagem com base na edição do texto latino de Robertson (1989). Observamos que a curiosidade de Lúcio, precisamente como a de Psiquê, é o elemento propulsor tanto para os percalços que ambos os personagens vão enfrentar, quanto por suas respectivas redenções. Como resultado, a história de Cupido e Psiquê pode ser percebida como uma fonte de jogos de espelhamentos que promovem uma interpretação mais aprofundada do romance apuleiano. $\mathrm{Na}$ segunda etapa, referente às imagens do leitor das Metamorfoses, visamos observar a relação que tais imagens possam ter com as narrativas sobrepostas da ficção apuleiana, sobretudo em relação ao jogo de espelhamentos, que se fazem notar, como mencionado acima, entre a história do narrador-protagonista e a de Cupido e Psiquê. Por meio das análises, observamos que a curiositas atua igualmente sobre a relação leitorpersonagem-narrador, na medida em que, após ser caracterizado como scrupulosus (Met. 9.30), optimus (Met. 10.2) e studiosus (Met. 11.23), o leitor evocado pelo texto também é advertido por sua curiosidade (Met. 11.23).

\section{Conclusões}

Ao analisar a curiositas e as imagens de leitor inscritas na ficção apuleiana, observamos que, como um dos efeitos da proximidade entre Lúcio, Psiquê e o lector (scrupulosus, studiosus, optimus) obtida pelo viés da curiosidade, ocorre a identificação do leitor com o próprio narrador-personagem. A partir dessa caracterização entre narrador-personagem-leitor, observamos que a curiositas é também associada ao processo narrativo, uma vez que tanto à sua produção (embasando, mais de uma vez, a verossimilhança relativa à autoridade do narrador), quanto à sua recepção, na medida em que também assim o leitor é caracterizado. Tudo leva a crer que haveria aqui - nos moldes do que defendem teóricos modernos, na linha de Teorias da Recepção (Jauss, 1994; Iser, 2002 [1989]) ou de "Reader-response criticism" (Fish, 1992) - um aceno para o reconhecimento da função que o leitor teria na narrativa do romance apuleiano, e se tal reconhecimento apontaria mesmo para uma dependência do papel do leitor, i.e. de dar coesão, ele mesmo, às mais frouxas relações entre as fabulae.

CARVER, R.H.F. The Protean Ass: The Metamorphoses of Apuleius from Antiquity, Oxford D.Phil.thesis. Oxford University Press. 2007 (1991).

HARRISON, S. J. "Constructing Apuleius: The Emergence of a Literary Artist”. Ancient Narrative, p. 143-171, 2003.

ISER, W. (2002 [1989]) "O jogo do texto". In: LIMA, L. C. (ed.); A literatura e o leitor: textos de estética da recepção. Rio de Janeiro, RJ: Paz e Terra, 2002, pp. 105-118.

ROBERTSON, D. S. (ed.) Apulée. Les Métamorphoses. Tradução de Paul Vallete. Paris: Les Belles Lettres, 1989, vol. 1,2,3. 